\title{
Cross Talk Between Brain Innate Immunity and Serotonin Signaling Underlies Depressive-Like Behavior Induced by Alzheimer's Amyloid- $\beta$ Oligomers in Mice
}

\author{
미ose Henrique Ledo, ${ }^{1}$ Estefania P. Azevedo, ${ }^{1}$ DDanielle Beckman, ${ }^{1}$ - Felipe C. Ribeiro, ${ }^{1}{ }^{\circ}$ Luis E. Santos, ${ }^{2}$ \\ ๑Daniela S. Razolli, ${ }^{4}$ Grasielle C. Kincheski, ${ }^{1}{ }^{\circ}$ Helen M. Melo, ${ }^{1}{ }^{\circledR}$ Maria Bellio, ${ }^{3}$ Antonio L. Teixeira, ${ }^{5}$ \\ ¿Licio A. Velloso, ${ }^{4}$-Debora Foguel, ${ }^{1}{ }^{\circ}$ Fernanda G. De Felice, ${ }^{1,6}$ and ${ }^{\circledR S}$ Sergio T. Ferreira ${ }^{1,2}$ \\ ${ }^{1}$ Institute of Medical Biochemistry Leopoldo de Meis, ${ }^{2}$ Institute of Biophysics Carlos Chagas Filho, and ${ }^{3}$ Institute of Microbiology Prof. Paulo de Goes, \\ Federal University of Rio de Janeiro, Rio de Janeiro, 21941-902 Brazil, ${ }^{4}$ Faculty of Medical Sciences, University of Campinas, Campinas, 13083-887 Brazil, \\ ${ }^{5}$ Faculty of Medicine, Federal University of Minas Gerais, Belo Horizonte, 30130-100 Brazil, and ${ }^{6}$ Centre for Neuroscience Studies, Department of \\ Biomedical and Molecular Sciences, Queen's University, Kingston, Ontario, K7L3N6 Canada
}

Considerable clinical and epidemiological evidence links Alzheimer's disease (AD) and depression. However, the molecular mechanisms underlying this connection are largely unknown. We reported recently that soluble $\mathrm{A} \beta$ oligomers (A $\beta 0$ s), toxins that accumulate in $\mathrm{AD}$ brains and are thought to instigate synapse damage and memory loss, induce depressive-like behavior in mice. Here, we report that the mechanism underlying this action involves A $\beta 0$-induced microglial activation, aberrant TNF- $\alpha$ signaling, and decreased brain serotonin levels. Inactivation or ablation of microglia blocked the increase in brain TNF- $\alpha$ and abolished depressive-like behavior induced by A $\beta 0$ s. Significantly, we identified serotonin as a negative regulator of microglial activation. Finally, A $\beta 0$ s failed to induce depressive-like behavior in Toll-like receptor 4-deficient mice and in mice harboring a nonfunctional TLR4 variant in myeloid cells. Results establish that $\mathrm{A} \beta 0$ s trigger depressive-like behavior via a double impact on brain serotonin levels and microglial activation, unveiling a cross talk between brain innate immunity and serotonergic signaling as a key player in mood alterations in AD.

Key words: Alzheimer's; depression; inflammation; microglia; serotonin

Significance Statement

Alzheimer's disease $(\mathrm{AD})$ is a progressive neurodegenerative disorder and the main cause of dementia in the world. Brain accumulation of amyloid- $\beta$ oligomers $(\mathrm{A} \beta \mathrm{Os})$ is a major feature in the pathogenesis of $\mathrm{AD}$. Although clinical and epidemiological data suggest a strong connection between $\mathrm{AD}$ and depression, the underlying mechanisms linking these two disorders remain largely unknown. Here, we report that aberrant activation of the brain innate immunity and decreased serotonergic tonus in the brain are key players in $\mathrm{A} \beta 0$-induced depressive-like behavior in mice. Our findings may open up new possibilities for the development of effective therapeutics for $\mathrm{AD}$ and depression aimed at modulating microglial function.

\section{Introduction}

Alzheimer's disease (AD) is a progressive neurodegenerative disorder and the main cause of dementia in the elderly. Brain in-

Received April 15, 2016; revised Sept. 20, 2016; accepted 0ct. 6, 2016.

Author contributions: J.H.L., E.P.A., and S.T.F. designed research; J.H.L., E.P.A., D.B., F.C.R., L.E.S., D.S.R., G.C.K., and H.M.M. performed research; M.B., A.L.T., L.A.V., D.F., and F.G.D.F. contributed unpublished reagents/analytic tools; J.H.L., E.P.A., D.B., F.C.R., L.E.S., M.B., D.F., F.G.D.F., and S.T.F. analyzed data; J.H.L., E.P.A., and S.T.F. wrote the paper.

This work was supported by grants from National Institute for Translational Neuroscience (STF), Conselho Nacional de Desenvolvimento Científico e Tecnológico (S.T.F. and F.G.D.F.), Fundação de Amparo à Pesquisa do Estado do Rio de Janeiro (S.T.F. and F.G.D.F.), and the Human Frontiers Science Program (F.G.D.F.). This study is dedicated to the memory of Prof. Leopoldo de Meis (1938 -2014), founder of the Institute for Medical Biochemistry at the Federal University of Rio de Janeiro.

The authors declare no competing financial interests. flammation is a neuropathological hallmark of $\mathrm{AD}$ and is recapitulated in experimental models of the disease (Heneka et al., 2014, 2015; Santos et al., 2016). Soluble oligomers of the amyloid- $\beta$ peptide $(\mathrm{A} \beta \mathrm{O}$ ) $)$, toxins that accumulate in the $\mathrm{AD}$ brain and are thought to trigger synapse failure and memory loss, have been implicated in key aspects of the pathogenesis of $\mathrm{AD}$ (Ferreira and Klein, 2011; Selkoe, 2011; Mucke and Selkoe, 2012; Benilova and De Strooper, 2013). We reported recently that

Correspondence should be addressed to Sergio T. Ferreira, Institute of Biophysics Carlos Chagas Filho and Institute of Medical Biochemistry Leopoldo de Meis, Federal University of Rio de Janeiro, Rio de Janeiro, RJ 21944 -590 Brazil. E-mail: ferreira@biogmed.ufri.br.

DOI:10.1523/JNEUROSCI.1269-16.2016

Copyright $\odot 2016$ the authors $\quad 0270-6474 / 16 / 3612106-11 \$ 15.00 / 0$ 
$\mathrm{A} \beta \mathrm{O}$ s trigger proinflammatory pathways, including astrocyte and microglial activation, in the brains of mice and nonhuman primates (Bomfim et al., 2012; Ledo et al., 2013; Lourenco et al., 2013; Forny-Germano et al., 2014) and that $\mathrm{A} \beta \mathrm{O}$-induced inflammatory signaling causes memory loss in mice (Lourenco et al., 2013).

Although most studies in AD have investigated mechanisms leading to memory/cognitive impairment, other symptoms that are an integral part of the disease have been relatively overlooked. Mood disturbances, including depression, have been reported to affect up to $90 \%$ of AD patients (Lyketsos and Olin, 2002) and are considered major risk factors for AD (Green et al., 2003; Ownby et al., 2006; (Starkstein and Mizrahi, 2006; Geerlings et al., 2008). Given the complex nature of $\mathrm{AD}$, a deeper understanding of mechanisms underlying major disease symptoms, including behavioral and mood disturbances, may contribute to the development of novel and successful therapies. We recently reported a molecular link between $\mathrm{AD}$ and depression by demonstrating that $\mathrm{A} \beta \mathrm{O}$ s induce both memory impairment and depressive-like behavior in mice (Ledo et al., 2013). Here, we aimed to determine the molecular mechanisms underlying the effects of $A \beta O$ s on behavioral abnormalities in mice. We hypothesized that $\mathrm{A} \beta \mathrm{O}-$ induced depressive-like behavior is caused by an inflammatory response triggered by microglial activation. To test this hypothesis, we investigated the molecular and functional outcomes of intracerebroventricular infusion of $\mathrm{A} \beta \mathrm{O}$ s in mice. Showing that microglia-derived TNF- $\alpha$ signaling triggers depressive-like behavior, inactivation/ablation of microglia or blockade of TNF- $\alpha$ with a neutralizing antibody prevented the behavioral impact of $\mathrm{A} \beta \mathrm{O}$ s. Importantly, A $\beta \mathrm{O}$ s decreased brain serotonin (5-HT) levels in mice, whereas treatment with 5 - $\mathrm{HT}$ prevented $\mathrm{A} \beta \mathrm{O}-$ induced microglial activation and increase in TNF- $\alpha$ levels. Results thus reveal a novel modulatory role of 5 -HT in brain inflammation. Further, A $\beta$ Os failed to reduce 5-HT levels or induce depressive-like behavior in Toll-like receptor 4-knockout (TLR $4^{-/-}$) mice and in chimeric mice harboring a nonfunctional TLR4 in cells of myeloid origin. This implicates microglial TLR4 as a novel and functionally relevant target of A $\beta O s$, triggering an inflammatory response that includes increased production and release of TNF- $\alpha$ and leading to depressive-like behavior in mice.

\section{Materials and Methods}

Reagents. 5-HT, 1,1,1,3,3,3,-hexafluoro-2-propanol (HFIP), dimethyl sulfoxide (DMSO), and poly-L-lysine were from Sigma-Aldrich. Culture media/reagents, Alexa Fluor-labeled secondary antibodies, and ProLong antifade reagent were from Invitrogen. BCA protein assay kit was from Pierce. Antibody against Iba- 1 was from Wako, and anti-F4/80 was from AbD Serotec. Synthetic $A \beta_{1-42}$ was from American Peptide.

Plasma sTNFR-1 levels in human subjects. Blood samples from AD patients or age- and sex-matched controls were from the Pietà study (Caramelli et al., 2011). Study participants were submitted to a comprehensive clinical evaluation that included cognitive evaluation (MiniMental State Examination and Brief Cognitive Screening Battery), functional evaluation administered to a close relative, and a structured psychiatric evaluation (Mini International Neuropsychiatric Interview, MINI). Clinical diagnosis of $\mathrm{AD}$ was performed according to the National Institute of Neurological and Communicative Disorders and Stroke (NINCDS) and the Alzheimer's Disease and Related Disorders Association (ADRDA) work group criteria. Control subjects presented with no cognitive impairment or psychiatric diagnosis. None of the participants had inflammatory or autoimmune diseases and none had taken antibiotics or immunosuppressive drugs for at least 4 weeks before the study. sTNFR-1 was measured in plasma by ELISA following the manufacturer's instructions (R\&D Systems).
$A \beta O s$. Synthetic $\mathrm{A} \beta_{1-42}$ was used to prepare $\mathrm{A} \beta \mathrm{O}$ s as described previously (Lambert et al., 1998). The peptide was first solubilized in HFIP and the solvent was evaporated to produce dried films. Films were then dissolved in sterile anhydrous DMSO to make a $5 \mathrm{~mm}$ solution, followed by dilution to $100 \mu \mathrm{M}$ in ice-cold PBS and incubation for $16 \mathrm{~h}$ at $4^{\circ} \mathrm{C}$. The preparation was centrifuged at $14,000 \times g$ for $10 \mathrm{~min}$ at $4^{\circ} \mathrm{C}$ to remove any insoluble aggregates and the supernatants containing soluble $\mathrm{A} \beta \mathrm{O}$ were removed carefully and stored at $4^{\circ} \mathrm{C}$. A $\beta$ Os were used within $48 \mathrm{~h}$ of preparation. Protein concentration was determined using BCA kit. Preparations were routinely characterized by HPLC size-exclusion chromatography under nondenaturing conditions and, occasionally, by SDSPAGE/Western blot using anti-A $\beta$ (6E10; Abcam) or anti-A $\beta \mathrm{O}$ NU4 (Lambert et al., 2007) (kindly provided by Dr. William L. Klein, Northwestern University). $\mathrm{A} \beta \mathrm{O}$ preparations were tested for endotoxin contamination using a commercial kit (Pierce) and showed no detectable levels of endotoxin (data not shown).

Animals, intracerebroventricular infusions, and other treatments. Threemonth-old male Swiss mice were used. Animals were housed in groups of five per cage with ad libitum access to food and water under a $12 \mathrm{~h}$ light/dark cycle with controlled temperature and humidity. All procedures followed the Principles of Laboratory Animal Care from the National Institutes of Health and were approved by the Institutional Animal Care and Use Committee of the Federal University of Rio de Janeiro (protocol \#IBqM 041/2011). For intracerebroventricular infusion of A $\beta$ Os (or vehicle) (Figueiredo et al., 2013), animals were anesthetized for 7 min with $2.5 \%$ isoflurane (Cristália) using a vaporizer system and gently restrained only during the injection procedure. A 2.5 -mm-long needle was inserted unilaterally $1 \mathrm{~mm}$ to the right of the midline point equidistant from each eye and $1 \mathrm{~mm}$ posterior to a line drawn through the anterior base of the eyes. Ten picomoles of $\mathrm{A} \beta \mathrm{O}$ s (or an equivalent volume of vehicle) were infused in a final volume of $3 \mu \mathrm{l}$. Accurate placement of the needle into the right lateral ventricle was confirmed by macroscopic examination of dissected brains. Mice showing any signs of misplaced injections or brain hemorrhage ( $\sim 7 \%$ of animals throughout our study) were excluded from further analysis.

Minocycline, diluted in saline at $\mathrm{pH}$ 7.0, was administered by intraperitoneal injection $(50 \mathrm{mg} / \mathrm{kg} / \mathrm{d})$ for 3 consecutive days ending on the day of $\mathrm{A} \beta \mathrm{O}$ injection. Liposome-encapsulated sodium clodronate $(5 \mathrm{mg}$ of clodronate $/ \mathrm{ml}$ of suspension, volume $=1.5 \mu \mathrm{l}$; ClodronateLiposomes.com) or PBS-containing liposomes (used as a control) were administered intracerebroventricularly once $3 \mathrm{~d}$ before $\mathrm{A} \beta \mathrm{O}$ infusion. Infliximab $(0.2 \mu \mathrm{g}$ in $2 \mu \mathrm{l})$ or saline $(2 \mu \mathrm{l})$ was administered intracerebroventricularly 30 min before $\mathrm{A} \beta \mathrm{O}$ infusion. Tryptophan hydroxylase inhibitor (p-chlorophenylalanine; Sigma-Aldrich) was diluted in PBS and administered by intraperitoneal injection $(250 \mathrm{mg} / \mathrm{kg}$ body weight $)$ for $3 \mathrm{~d}$ before intracerebroventricular infusion of $\mathrm{A} \beta \mathrm{Os}$.

TLR4 ${ }^{-1-}$ mice and chimeric mice harboring a nonfunctional TLR4 mutation were maintained at the animal facility of the University of Campinas following procedures approved by the Institutional Animal Care and Use Committee of the University of Campinas (protocol \#2397-1).

In some experiments (see "Results"), APP/PS1 mice were used. These were bred and maintained in our animal facility and used at 8-9 months of age. Age-matched wild-type littermates were used as controls.

Forced swim test (FST). The FST was performed as described previously (Porsolt et al., 1977; Autry et al., 2011) with slight modifications. Mice were placed for $6 \mathrm{~min}$ in a $4 \mathrm{~L}$ Pyrex glass beaker containing $3 \mathrm{~L}$ of water at $24 \pm 1^{\circ} \mathrm{C}$. Water was changed between animals. A trained researcher blinded to group assignment recorded immobility time using a stopwatch. An increase in immobility time indicates depressive-like behavior.

Sucrose preference test. Mice were kept in individual cages and given a free choice between two bottles, one containing a $2 \%$ sucrose solution and another with plain water. The volume of consumed water and sucrose solution was measured daily. After preference for sucrose solution was reached (which typically took $\sim 2-4 \mathrm{~d}$ ), mice were infused intracerebroventricularly with $\mathrm{A} \beta \mathrm{O}$ s, vehicle ( $2 \% \mathrm{DMSO}$ in PBS), heat-denatured $\mathrm{BSA}$, or scrambled $\mathrm{A} \beta$ peptide. After $24 \mathrm{~h}$ of recovery, sucrose preference 
was assessed as described above. Sucrose preference was expressed as the ratio between the volumes of sucrose solution or plain water consumed.

Primary cultures of mouse microglia. Primary microglial cultures were prepared as described previously (Azevedo et al., 2013). Mouse cortices were dissociated in culture medium containing DMEM/F12 supplemented with $10 \%$ fetal bovine serum and $1 \%$ gentamicin. Cells were incubated in $75 \mathrm{~cm}^{2}$ flasks for 2 weeks at $37^{\circ} \mathrm{C}, 5 \% \mathrm{CO}_{2}$. After 2 weeks, microglia were isolated by shaking for $1 \mathrm{~h}$ in an orbital shaker and plated at $5 \times 10^{4}$ cells/well in 96-well plates, $1 \times 10^{5}$ cells/well in 24 -well plates. Cultures were treated at $37^{\circ} \mathrm{C}$ for different time periods with $100 \mathrm{~nm}$ $\mathrm{A} \beta \mathrm{O}$ s or an equivalent volume of vehicle (0.2\% DMSO in PBS). E. coli lipopolysaccharide (LPS, $100 \mathrm{ng} / \mathrm{ml}$ ) was used as a positive control for microglial activation. When present, 5- $\mathrm{HT}(1 \mu \mathrm{M})$ was added to cultures 30 min before $\mathrm{A} \beta \mathrm{O}$. As noted above, $\mathrm{A} \beta \mathrm{O}$ preparations tested negative for endotoxin contamination. In any case, as an added measure to ensure that experimental results were not affected by eventual and minor (below detection limit) endotoxin contamination in $\mathrm{A} \beta \mathrm{O}$ s or other reagents, polymyxin $\mathrm{B}(10 \mu \mathrm{g} / \mathrm{ml})$ was added routinely to the culture medium in all experimental conditions.

Determination of TNF- $\alpha$, sTNFR1, and nitric oxide (NO). Whole brains or hippocampi were homogenized in PBS with protease and phosphatase inhibitors (Pierce) on ice and centrifuged at 15,000 rpm for $10 \mathrm{~min}$ at $4^{\circ} \mathrm{C}$. Supernatants were collected for protein determination using BCA kit (Thermo Fisher Scientific). ELISA assays for TNF- $\alpha$ (BioLegend) or sTNFR1 (R\&D Systems) were performed according to the manufacturer's instructions.

TNF- $\alpha$ released by primary microglial cultures $\left(5 \times 10^{4}\right.$ cells/well $)$ during a $24 \mathrm{~h}$ period was measured using an in situ ELISA protocol. Plates were UV sterilized for $30 \mathrm{~min}$ and coated with anti-TNF- $\alpha$ monoclonal capture antibody (Peprotech) for $24 \mathrm{~h}$ at $25^{\circ} \mathrm{C}$. Plates were washed 4 times with washing buffer (PBS, pH 7.2, containing $0.05 \%$ Tween 20 ) and blocked using $1 \% \mathrm{BSA}$ for $1 \mathrm{~h}$ at $25^{\circ} \mathrm{C}$. Microglia were then plated onto the wells and incubated for $1 \mathrm{~h}$ at $37^{\circ} \mathrm{C}, 5 \% \mathrm{CO}_{2}$. Cells were treated for $24 \mathrm{~h}$ with vehicle, LPS (100 ng/ml), A $\beta$ Os ( $100 \mathrm{nM})$, or 5-HT ( $1 \mu \mathrm{M})$ or were pretreated with $5-\mathrm{HT}(1 \mu \mathrm{M})$, followed by A $\beta$ Os (100 nM). After $24 \mathrm{~h}$, plates were washed extensively and incubated with anti-TNF- $\alpha$ polyclonal detection antibody conjugated with biotin (Peprotech) for $2 \mathrm{~h}$ at $25^{\circ} \mathrm{C}$ followed by streptavidin-HRP (Zymed) for $1 \mathrm{~h}$ at $25^{\circ} \mathrm{C}$. Detection was performed using $O$-phenylenediamine (Sigma-Aldrich) and color development was monitored at $490 \mathrm{~nm}$ using an ELISA plate reader (SpetraMax Paradigm Reader; Molecular Devices). TNF- $\alpha$ levels were quantified using a recombinant TNF- $\alpha$ standard curve.

For NO determination, primary microglia cultures $\left(5 \times 10^{4}\right.$ cells/well $)$ were treated as described above for $48 \mathrm{~h}$. Griess reagents (1\% sulfanilamide and $0.1 \%$ naphthylethylenediamino dihydrochloride; $100 \mu \mathrm{l}$ ) were added to $100 \mu \mathrm{l}$ of culture supernatants, homogenized, transferred to the original well, and further homogenized with cells. Color development was monitored using an ELISA plate reader at $540 \mathrm{~nm}$ and micromolar nitrite levels were estimated using a sodium nitrite standard curve.

Immunocytochemistry. Cells were fixed in $4 \%$ paraformaldehyde for 20 $\mathrm{min}$ at room temperature and blocked in $10 \%$ normal goat serum diluted in PBS, incubated with anti-F4/80 mouse monoclonal antibody (1:50; AbDSerotec) or anti-Iba-1 rabbit polyclonal antibody (1:400; Wako) followed by Alexa Fluor-conjugated secondary antibodies (1:500; Invitrogen). Coverslips were imaged on a Zeiss Axio Observer Z1 microscope using $20 \times$ or $40 \times$ objectives.

Immunohistochemistry. Animals were anesthetized and perfused with saline, followed by $4 \%$ paraformaldehyde in $0.1 \mathrm{~m}$ phosphate buffer, $\mathrm{pH}$ 7.4. Fixed brains were removed and cryoprotected in increasing concentrations of sucrose. Frozen $40 \mu \mathrm{m}$ coronal brain sections were made on a cryostat (Leica Microsystems) and stored in Tris-buffered saline, 0.05\% sodium azide, $30 \%$ glycerol, and $15 \%$ sucrose at $4^{\circ} \mathrm{C}$. Free-floating immunohistochemistry was performed after washing the sections extensively with PBS. Groups of 5-7 sections per animal were incubated in 15 $\mathrm{mm}$ wells for $2 \mathrm{~h}$ with $0.25 \%$ Triton X-100, 3\% BSA, and 3\% normal donkey serum. After this blocking step, sections were incubated overnight with anti-Ibal primary antibody (1:500; Wako) diluted in PBS. Sections were then washed and incubated for $2 \mathrm{~h}$ with an Alexa Fluor 594-conjugated secondary antibody (1:800; Life Technologies). After a
Table 1. Primer sequences used in $P(R$ amplification

\begin{tabular}{lll}
\hline Target gene & Forward primer $\left(3^{\prime} \rightarrow 5^{\prime}\right)$ & Reverse primer $\left(3^{\prime} \rightarrow 5^{\prime}\right)$ \\
\hline 185 & CCG CCG CCA TGT CTC TAG T & CAT GAG CAT ATC TCC GCC CC \\
GATA1 & CCT TGT GAG GCC AGA GAG TG & CGC CAG AGT GTT GTA GTG GT \\
Ido 1 & TGG TGG AAA TCG CAG CTT CT & TCC CAG ACC CCC TCA TAC AG \\
S100A10 (p11) & ATG CCA TCC CAA ATG GAG CA & GAA CTC CCG TTC CAT GAG CA \\
TNF- $\alpha$ & CCC TCA CAC TCA GAT CAT CTT CT & GCT ACG ACG TGG GCT ACA G \\
BDNF & TAA ATG AAG TTT ATA CAG TAC AGT & AGT TGT GCG CAA ATG ACT GTT T \\
& GGT TCT ACA & \\
\hline
\end{tabular}

final washing step, sections were briefly stained with DAPI and mounted with $n$-propyl gallate. Images were acquired on a TE2000 Nikon microscope.

Brain levels of 5-HT. 5-HT levels in mouse brains were measured by HPLC coupled with electrochemical detection (HPLC-ED; Shimadzu). Briefly, animals were decapitated and brains dissected in ice-cold PBS. Perchloric acid was added to each sample to a final concentration of 0.1 M. Samples were sonicated $(2 \times 5 \mathrm{~s}$ pulses, $50 \mathrm{~Hz})$ and centrifuged $(14,000 \times g, 10 \mathrm{~min})$ to remove precipitated proteins, protein quantification was further measured using BCA kit. Supernatants were used for HPLC-ED analysis. Isocratic separation was performed on a reversephase LC-18 column ( $4.6 \mathrm{~mm} \times 250 \mathrm{~mm}$; Sigma-Aldrich) using $20 \mathrm{~mm}$ $\mathrm{Na}_{2} \mathrm{HPO}_{4}, 20$ mM citric acid, $10 \%$ methanol, $0.12 \mathrm{~mm} \mathrm{Na}_{2}$ EDTA, and 566 $\mathrm{mg} / \mathrm{L}$ heptanesulphonic acid, $\mathrm{pH} 2.64$, as mobile phase.

$N F-\kappa B$ assay. Primary mouse microglia $\left(10^{5}\right.$ cells $)$ were plated in $24-$ well plates. Cells were incubated with $100 \mathrm{~nm} \mathrm{~A} \beta O$ s or an equivalent volume of vehicle for $2 \mathrm{~h}$, fixed in $4 \%$ paraformaldehyde, incubated in blocking/permeabilizing solution (PBS containing 5\% normal goat serum and $0.3 \%$ Triton $\mathrm{X}-100$ ) for $1 \mathrm{~h}$ at room temperature, and incubated overnight at $4^{\circ} \mathrm{C}$ with rabbit anti-mouse NF $\kappa \mathrm{B}$ p65 (1:50 dilution; Cell Signaling Technology), followed by incubation with Alexa Fluor 546conjugated goat anti-rabbit IgG (1:500; Cell Signaling Technology) for $1 \mathrm{~h}$ at room temperature. A total of 20 images were acquired per experimental condition in each of four independent experiments with different microglial cultures.

$R T-P C R$. Total RNA was isolated using the SV RNA isolation kit (Promega) according to manufacturer's instructions. Reverse transcription was performed using the High-Capacity cDNA reverse transcription kit (Life Technologies) according to the manufacturer's instructions using a thermocycler (AmpliTherm TX25; Ideal Lab). PCR amplification using specific primer sets (Table 1) was performed at $95^{\circ} \mathrm{C}$ for $10 \mathrm{~min}$ and $15 \mathrm{~s}$, $60^{\circ} \mathrm{C}$ for $1 \mathrm{~min}, 95^{\circ} \mathrm{C}$ for $15 \mathrm{~s}, 60^{\circ} \mathrm{C}$ for $1 \mathrm{~min}$, and $95^{\circ} \mathrm{C}$ for $15 \mathrm{~s}$, repeated for 40 cycles in a 7500 Real Time PCR System (Applied Biosystems). $18 \mathrm{~S}$ ribosomal RNA was used as a control to evaluate relative expression of all other genes. mRNA levels are expressed using the $2^{-\Delta \Delta \mathrm{Ct}}$ method (Schmittgen and Livak, 2008). Primer sequences used for PCR are shown in Table 1:

Irradiation and bone marrow transplantation (BMT). Six week-old male C3H/HeJ (HJ, TLR4-mutant; Poltorak et al., 1998) or C3H/HePas (HP, WT) mice were exposed to a single 8 Gray session of total body irradiation using a cobalt-60 source (Theratron-780 model; MDS Nordion). Twenty-four hours after irradiation, each animal was injected via the tail vein with at least $5 \times 10^{6}$ bone marrow cells freshly collected from a donor mouse. Cells were aseptically harvested by flushing donor femurs with Dulbecco's PBS (DPBS) containing 2\% FBS, followed by filtration through a $40 \mu \mathrm{m}$ nylon mesh and centrifugation at room temperature for $10 \mathrm{~min}$ at $1000 \mathrm{rpm}$. Cells were resuspended in DPBS and $5 \times 10^{6}$ cells in $200 \mu \mathrm{l}$ of the cell suspension were injected per mice. Irradiated mice transplanted with this cell suspension were housed in autoclaved cages and treated with antibiotics $(0.2 \mathrm{mg}$ of trimethoprim $/ \mathrm{ml}$ and $1 \mathrm{mg}$ of sulfamethoxazole $/ \mathrm{ml}$ ) in the drinking water for $4 \mathrm{~d}$ before and $7 \mathrm{~d}$ after irradiation.

Data analysis. All in vitro and in vivo experiments (except for the BMT experiment, which was performed once with groups of six to eight mice per experimental condition) were performed three to six times using independent microglial cultures or different groups of animals and different $\mathrm{A} \beta \mathrm{O}$ preparations. Immunofluorescence intensity data were ana- 
A

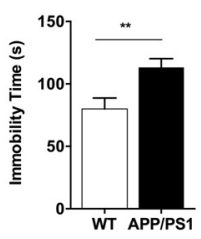

B

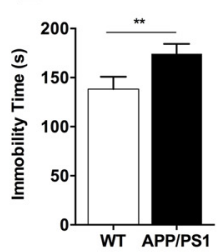

C

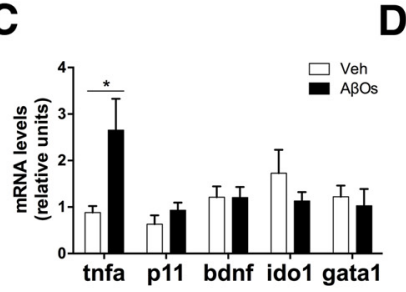

D

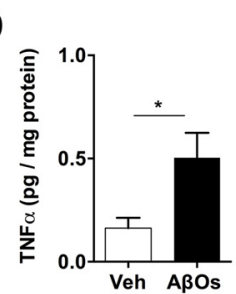

E

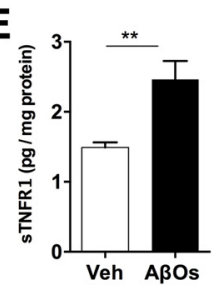

F

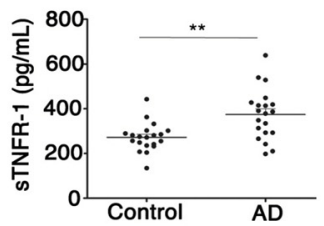

G

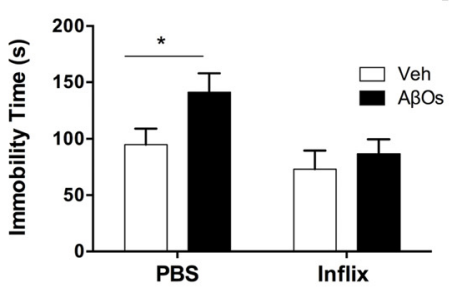

K
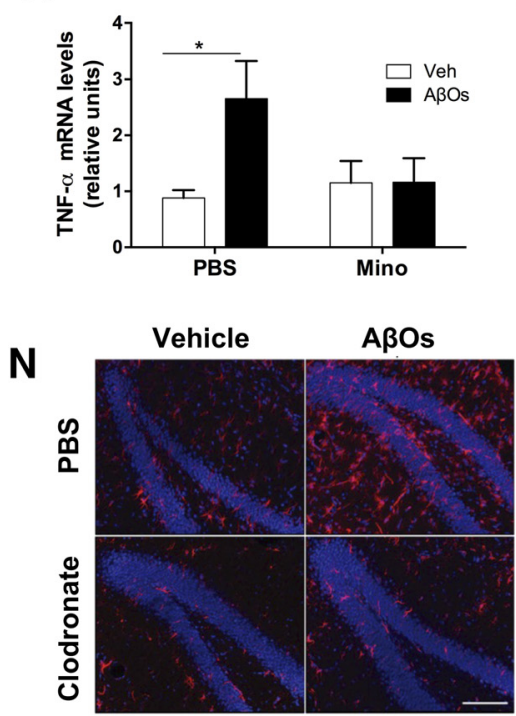

H

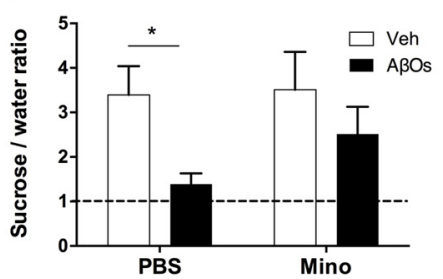

L

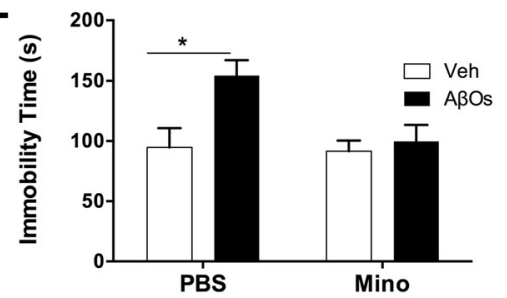

0

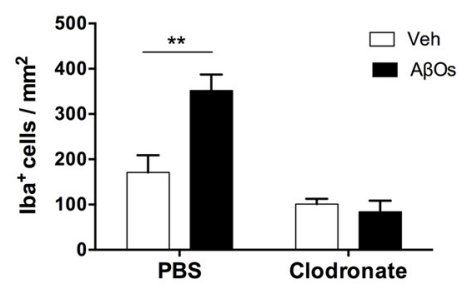

J

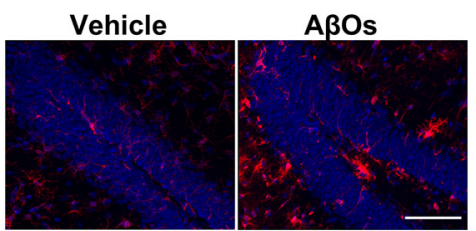

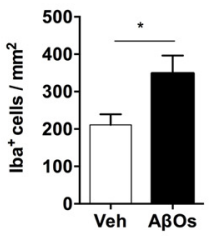

M

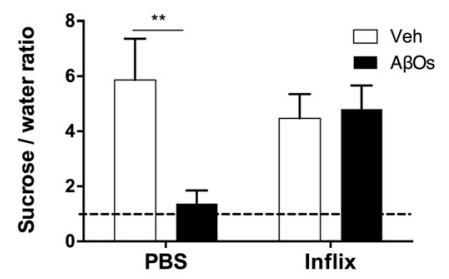

P

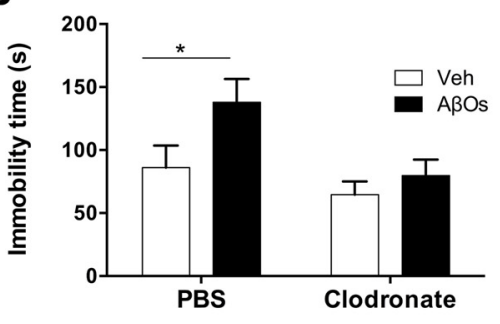

Figure 1. Microglial activation and TNF- $\alpha$ signaling underlie A $\beta 0$-induced depressive-like behavior in mice. $\boldsymbol{A}, \boldsymbol{B}$, WT or APP/PS1 mice ( $8-9$ months old) were tested in the FST (A) or tail suspension test $(\boldsymbol{B}) . n=7-11$ mice per group. $\boldsymbol{C}$, Swiss mice ( 3 months old) received a single intracerebroventricular infusion of $10 \mathrm{pmol}$ of $\mathrm{A} \beta 0 \mathrm{~s}$ (or vehicle). $q \mathrm{RT}-\mathrm{PCR}$ was performed $24 \mathrm{~h}$ after $\mathrm{A} \beta 0$ infusion. $n=8$ mice per group. $\boldsymbol{D}, \boldsymbol{E}$, Brain TNF- $\alpha(\boldsymbol{D})$ and sTNFR1 $(\boldsymbol{E})$ levels in hippocampal extracts from A $\beta 0$-infused Swiss mice. $n=8-10$ mice per group. $\boldsymbol{F}$, Plasma levels of sTNFR1 in AD patients or age- and sex-matched controls. $\boldsymbol{G}, \boldsymbol{H}$, Mice were injected intracerebroventricularly with infliximab $30 \mathrm{~min}$ before $\mathrm{A} \beta 0$ infusion. FST $(\boldsymbol{G})$ or sucrose preference test $(\boldsymbol{H})$ was performed $24 \mathrm{~h}$ after A $\beta 0$ infusion. $n=14-15$ mice per group in the FST group; $n=6-7$ per group in the sucrose preference test group. $I$, Representative immunohistochemistry images for Iba- 1 (red) in hippocampal sections from A $\beta 0$ - or vehicle-injected Swiss mice. Nuclei are in blue (DAPI). $n=4$ per group ( 20 images per animal). Scale bar, $50 \mu \mathrm{m}$. $J$, Quantification of Iba- ${ }^{+}$cells in the dentate gyrus of mice infused with $A \beta 0$ s or vehicle. $\boldsymbol{K}-\boldsymbol{M}$, Swiss mice received daily intraperitoneal injections of vehicle (saline) or minocycline $(50 \mathrm{mg} / \mathrm{kg} / \mathrm{d})$ for $3 \mathrm{~d}$ before intracerebroventricular infusion of A $\beta 0$ s or vehicle. qRT-PCR for determination of TNF- $\alpha$ expression was performed $24 \mathrm{~h}$ after $A \beta 0$ injection $(\boldsymbol{K}) . n=6-8$ per group. FST $(\boldsymbol{L})$ or sucrose preference test $(\boldsymbol{M})$ was performed $24 \mathrm{~h}$ after $\mathrm{A} \beta 0$ infusion. $n=17-23$ per group in the FST group; $n=6-7$ in the sucrose preference test group. $\boldsymbol{N}-\boldsymbol{P}$, Clodronate- or PBS-containing liposomes were administered intracerebroventricularly to mice in a single dose $3 \mathrm{~d}$ before $A \beta 0$ or vehicle infusion. $\boldsymbol{N}$, Brains were processed for immunohistochemistry $24 \mathrm{~h}$ after $\mathrm{A} \beta 0$ injection. Hippocampal sections were labeled with anti-lba- 1 (red) and DAPI (blue). Scale bars, $50 \mu \mathrm{m} . n=3-5$ mice per experimental group (20 hippocampal images per animal). 0 , Quantification of Iba- ${ }^{+}$cells in the dentate gyrus of mice infused with A $30 \mathrm{~s}$ or vehicle that had been treated previously or not with clodronate. $\boldsymbol{P}$, FST performed $24 \mathrm{~h}$ after A $\beta 0$ injection. $n=9-11$ per group. In all panels, bars represent means \pm SEM, ${ }^{*} p \leq 0.05$, ${ }^{* *} p \leq 0.01(\boldsymbol{A}, \boldsymbol{B}$, Welch's $t$ test; $\boldsymbol{C}-\boldsymbol{E}, \boldsymbol{J}$, Student's $t$ test; $\boldsymbol{F}$, Mann-Whitney $U$ test; $\boldsymbol{G}, \boldsymbol{K}, \boldsymbol{L}, \boldsymbol{M}, \mathbf{O}, \boldsymbol{P}$, two-way ANOVA followed by Dunnett's multiple-comparisons test).

lyzed using NIH ImageJ. Data are presented as means \pm SEM. Statistical significance was determined using GraphPad Prism software and Welch's $t$ test, two-tailed Student's $t$ test, or two-way ANOVA with suitable post hoc analysis, as indicated in the figure legends.

\section{Results}

Microglial activation and aberrant TNF- $\alpha$ signaling mediate depressive-like behavior induced by $\mathrm{A} \beta \mathrm{O}$ s

Depressive-like behavior has been reported in transgenic models of AD (Filali et al., 2009; Frye and Walf, 2009; Romano et al., 2014). Here, we first extended those findings using APPSwe/ PS1 $\Delta \mathrm{E} 9$ mice, a well characterized AD model (Fig. $1 A, B$ ). Con- sistent with findings in transgenic $\mathrm{AD}$ models, we reported recently that a single intracerebroventricular infusion of $\mathrm{A} \beta \mathrm{O}$ s (10 pmol) induces depressive-like behavior and cognitive deficit in mice (Ledo et al., 2013). In an effort to elucidate the mechanisms underlying this effect, we initially investigated whether proteins implicated in depressive-like behavior in mice or in human depressive disorder might mediate the impact of $\mathrm{A} \beta \mathrm{O}$. We examined the expression levels of p11 (also known as S100A10, nerve growth factor-induced protein $42 \mathrm{C}$, calpactin I light chain, or annexin II light chain; Svenningsson et al., 2006, 2013), BDNF (Schmidt and Duman, 2007; Anon, 2008), GATA-1 (an erythroid 
A

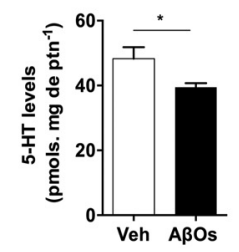

B

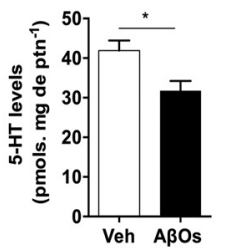

C

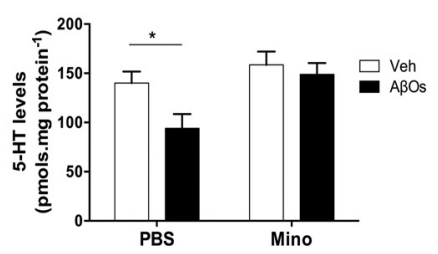

D

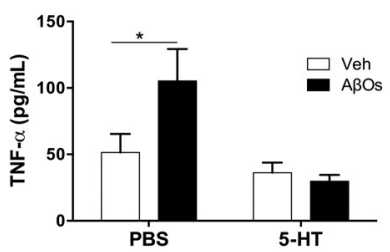

E

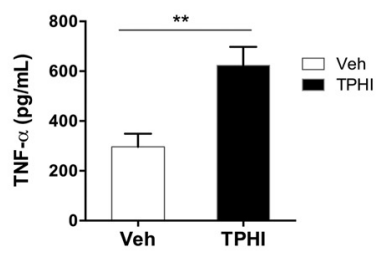

Figure 2. 5 -HT blocks $A \beta 0$-induced microglial activation and elevated TNF- $\alpha$ production and release. $\boldsymbol{A}, \boldsymbol{B}, 5$-HT levels measured in the hippocampus $(\boldsymbol{A})$ or prefrontal cortex $(\boldsymbol{B}) 10 \mathrm{~d}$ after intracerebroventricular infusion of $\mathrm{A} \beta 0$ s in mice. $n=8-10$ mice per group. $\boldsymbol{C}$, Brain 5-HT levels after intracerebroventricular infusion in minocycline-treated or saline-treated mice. Minocycline treatment was performed for 3 consecutive days between 7 and $10 \mathrm{~d}$ after $\mathrm{A} \beta 0$ infusion. $n=8-9$ mice per group. $D$, Mice received an intracerebroventricular injection of 5 -HT ( 100 pmol) 30 min before injection of $A \beta 0$ s (or vehicle). Brain TNF- $\alpha$ was measured $4 \mathrm{~h}$ after injection of $A \beta 0 \mathrm{~s} . n=10-11$ per group. $E$, Tryptophan hydroxylase inhibitor (TPHI) was administered intraperitoneally twice a day $(250 \mathrm{mg} / \mathrm{kg})$ for $3 \mathrm{~d}$. Brain TNF- $\alpha$ levels were quantified $24 \mathrm{~h}$ after the last injection. $n=6-8$ mice per group. Error bars indicate means $\pm \mathbf{S E M},{ }^{*} p \leq 0.05,{ }^{* *} p \leq 0.01(\boldsymbol{A}, \boldsymbol{B}, \boldsymbol{E}$, Student's $t$ test; $C, D$, two-way ANOVA followed by Dunnett's multiple-comparisons test).

transcription factor) (Kang et al., 2012) and indoleamine-2,3dioxygenase (Wichers et al., 2005; Dantzer et al., 2008) in mouse brains after intracerebroventricular infusion of $\mathrm{A} \beta \mathrm{O}$. No changes in mRNA levels were detected for any of these proteins either $24 \mathrm{~h}$ (Fig. 1C) or $10 \mathrm{~d}$ (data not shown) after infusion. Interestingly, a robust increase in brain expression of TNF- $\alpha$, a proinflammatory cytokine implicated in depressive behavior (Zhu et al., 2006; Dantzer et al., 2008) and recently found to mediate $\mathrm{A} \beta \mathrm{O}$-induced memory impairment in mice (Lourenco et al., 2013), was verified $24 \mathrm{~h}$ after infusion of A $\beta O$ s (Fig. $1 C$ ). Increased brain expression of TNF- $\alpha$ persisted for $8 \mathrm{~d}$ after $\mathrm{A} \beta \mathrm{O}$ infusion (data not shown). We further found increased hippocampal levels of TNF- $\alpha$ (Fig. $1 D$ ) and soluble TNF- $\alpha$ receptor 1 (sTNFR1; Fig. 1E) $5 \mathrm{~h}$ after infusion of A $\beta \mathrm{O}$ in mice. Underlining the pathophysiological relevance of elevated TNF- $\alpha$ signaling in $\mathrm{AD}$, significantly higher plasma levels of sTNFR1 were verified in $\mathrm{AD}$ patients compared with age-matched healthy subjects (Fig. $1 F)$.

We next sought to determine whether elevated brain TNF- $\alpha$ levels triggered depressive-like behavior in mice. Intracerebroventricular treatment of mice with infliximab, a TNF- $\alpha$ neutralizing monoclonal antibody, blocked depressive-like behavior induced by $\mathrm{A} \beta \mathrm{O}$, as assessed by both the FST and sucrose preference test (Fig. $1 G, H$ ). Control experiments showed that intracerebroventricular infusion of aggregated (heat-denatured) BSA or scrambled $A \beta$ did not induce anhedonic behavior in the sucrose preference test (data not shown).

Immunohistochemical analysis revealed a dramatic increase in density of Iba-1-positive cells in the hippocampi of $\mathrm{A} \beta \mathrm{O}$ infused mice (Fig. 1I,J). We thus investigated whether activated microglia were the source of elevated brain TNF- $\alpha$ levels in $\mathrm{A} \beta \mathrm{O}-$ infused mice. Pretreatment of mice with minocycline, an inhibitor of microglial polarization to a more proinflammatory state (classically described as the M1 state (Kobayashi et al., 2013; Bie et al., 2014), blocked the increase in brain TNF- $\alpha$ mRNA levels induced by $\mathrm{A} \beta \mathrm{O}$ s (Fig. $1 K$ ). Minocycline treatment further prevented the increase in immobility time in the FST (Fig. $1 L$ ) and the decrease in sucrose preference (Fig. $1 M$ ) induced by $\mathrm{A} \beta \mathrm{Os}$.

To further investigate the role of microglia in depressivelike behavior induced by $\mathrm{A} \beta \mathrm{O}$, we performed selective ablation of microglia in mice using liposome-encapsulated sodium clodronate (van Rooijen and Hendrikx, 2010). Mice received a suspension of clodronate-containing liposomes (or PBS-containing liposomes as a control) delivered intracerebroventricularly $3 \mathrm{~d}$ before the infusion of $\mathrm{A} \beta \mathrm{O}$ s. Clodronate treatment blocked the increase in Iba-1-positive cells induced by $\mathrm{A} \beta \mathrm{O}$ s (Fig. $1 \mathrm{~N}, \mathrm{O}$ ). A $\beta \mathrm{O}$ s failed to induce an increase in immobility time in the FST in clodronate-treated mice (Fig. $1 P)$. Results thus suggest that microglia are the source of TNF- $\alpha$ production and mediate depressive-like behavior induced by $\mathrm{A} \beta \mathrm{Os}$.

\section{Disruption of serotonergic signaling by $\mathrm{A} \beta \mathrm{O}$ s contributes to brain inflammation}

Serotonergic neurotransmission is compromised in major depression disorder and in AD (Bonaccorso et al., 1998; Anon, 2008; Rodríguez et al., 2012). Nonetheless, whereas the role of 5 -HT is well established in depression, the relationship between deregulated 5-HT signaling and $\mathrm{AD}$ is not well understood. We hypothesized that neuroinflammation triggered by $\mathrm{A} \beta \mathrm{O}$ s might lead to altered 5-HT levels. To test this hypothesis, we measured brain 5-HT levels in A $\beta \mathrm{O}$-infused mice. Compared with vehicleinjected mice, levels of 5-HT were reduced significantly $10 \mathrm{~d}$ after infusion of $\mathrm{A} \beta \mathrm{O}$ s in both hippocampus (Fig. $2 A$ ) and prefrontal cortex (Fig. $2 B$ ), brain regions affected in $\mathrm{AD}$ and depression. Minocycline treatment blocked this decrease (Fig. 2C). Results indicate that $\mathrm{A} \beta \mathrm{O}$ s disrupt 5 -HT homeostasis in a microgliadependent manner.

We next investigated whether, conversely, 5-HT might counteract the deleterious impact of $\mathrm{A} \beta \mathrm{O}$ s. To address this question, we injected 5 -HT (100 pmol) or an equivalent volume of saline intracerebroventricularly in mice $30 \mathrm{~min}$ before intracerebroventricular infusion of $\mathrm{A} \beta \mathrm{O}$ s and analyzed TNF- $\alpha$ levels in brain extracts $4 \mathrm{~h}$ later (Fig. $2 D$ ). Interestingly, pretreatment with 5-HT blocked the increase in brain TNF- $\alpha$ levels induced by A $\beta$ Os. We further sought to determine whether endogenous 5-HT signaling regulates TNF- $\alpha$ levels in a physiological range. We measured levels of TNF- $\alpha$ in brain extracts from mice treated intraperitoneally with saline or PCPA, an inhibitor of tryptophan hydroxylase, the enzyme that catalyzes the rate-limiting step in 5-HT synthesis. Inhibition of 5-HT production increased TNF- $\alpha$ levels in the mouse brain (Fig. 1E).

\section{5-HT prevents $\mathrm{A} \boldsymbol{\beta} \mathrm{O}$-induced activation of microglia}

The results presented above established that $\mathrm{A} \beta \mathrm{O}$ s activate microglia in vivo. However, whether activation was caused by a direct impact of $\mathrm{A} \beta \mathrm{O}$ s on microglia or if it was mediated by signaling from other cell types, notably neurons, remained to be determined. To gain insight into this question, we exposed purified primary cultures of mouse microglia to a low concentration of $\mathrm{A} \beta \mathrm{Os}$ (100 nM). Live/dead labeling of microglial cultures showed no indication of cell death upon exposure to $\mathrm{A} \beta \mathrm{O}$ s for up to $24 \mathrm{~h}$ (data not shown). Exposure of cultures to $\mathrm{A} \beta \mathrm{O}$ s for $24 \mathrm{~h}$ induced marked morphological changes, with increased cell area 

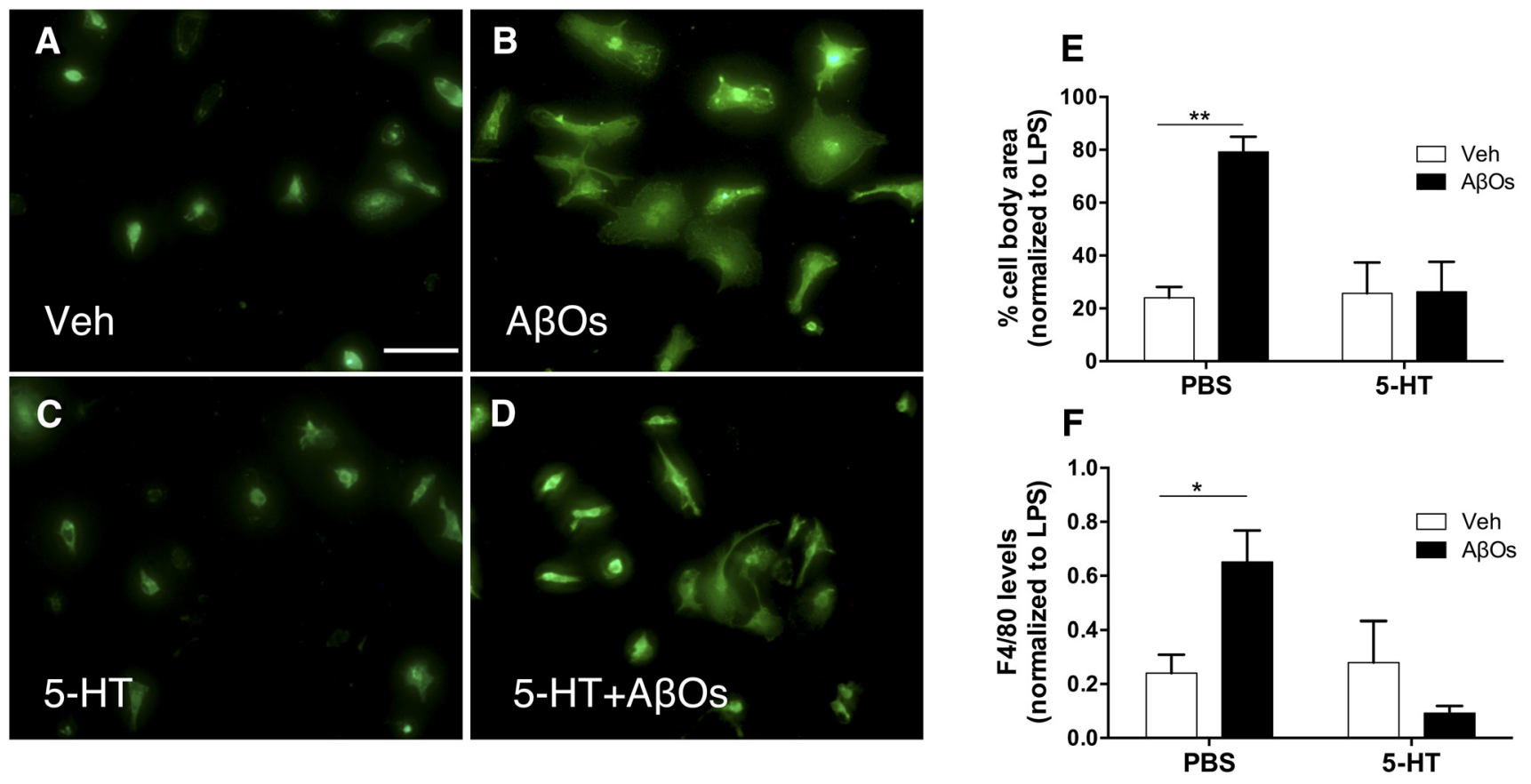

G

H

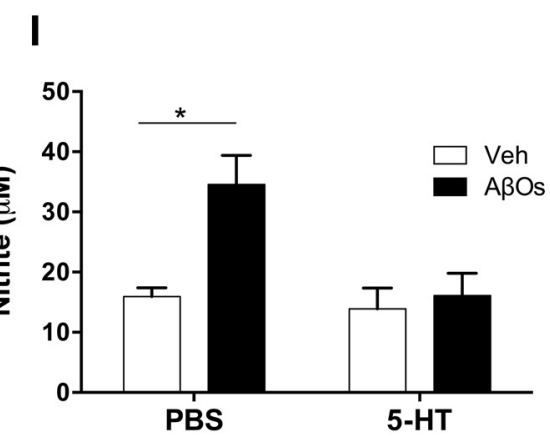

Figure 3. 5 -HT blocks A $\beta 0$-induced microglial activation and elevated TNF- $\alpha$ production and release. $A-D$, Purified mouse microglia cultures were pretreated (as indicated) with $1 \mu \mathrm{m} 5$-HT for $30 \mathrm{~min}$ before the addition of $100 \mathrm{~nm} \mathrm{~A} \beta 0$ s (or vehicle) to the culture medium, followed by incubation for $24 \mathrm{~h}$ at $37^{\circ} \mathrm{C}$. Representative images of $\mathrm{F} 4 / 80$ immunofluorescence labeling (green) are shown. Scale bar, $50 \mu \mathrm{m}$. $E$, Cell body areas were measured using ImageJ. Error bars indicate means \pm SEM; $n=3$ independent microglial cultures ( 3 coverslips per culture; $10 \mathrm{images}$ acquired per coverslip); two-way ANOVA followed by Dunnett's multiple-comparisons test, ${ }^{* *} p \leq 0.01 . F$, Integrated F4/80 immunofluorescence. $n=3-4$ independent microglial cultures ( 3 coverslips per culture; 10 images acquired per coverslip). Error bars indicate means \pm SEM; two-way ANOVA followed by Dunnett's multiple-comparisons test, ${ }^{*} p \leq 0.05$. G, Microglial cultures were incubated with $100 \mathrm{~nm} \mathrm{~A} \beta 0$ s or vehicle for $2 \mathrm{~h}$ before determination of TNF- $\alpha$ mRNA levels. Error bars indicate means \pm SEM; $n=3$ independent microglial cultures, 2 replicate determinations per experimental condition per culture; ${ }^{*} p \leq 0.05$ (Student's $t$ test). $\boldsymbol{H}$, Microglial cultures were pretreated with $1 \mu \mathrm{m} 5$-HT for 30 min and further incubated with $100 \mathrm{~nm} A \beta 0 \mathrm{~s}$ (or vehicle) for $24 \mathrm{~h}$ before measurement of TNF- $\alpha$ protein levels. Error bars indicate means \pm SEM; $n=3$ independent microglial cultures, $2-3$ replicate determinations per experimental condition per culture; two-way ANOVA followed by Dunnett's multiple-comparisons test, ${ }^{* *} p \leq 0.01$. I, Cultures were pretreated with $1 \mu \mathrm{m} 5$-HT for 30 min and further incubated with $100 \mathrm{~nm} \mathrm{~A} \beta 0 \mathrm{~s}$ (or vehicle) for $24 \mathrm{~h}$ to before measurement of nitrite levels. Error bars indicate means \pm SEM; $n=3$ independent microglial cultures, $2-3$ replicate determinations per experimental condition per culture; two-way ANOVA followed by Dunnett's multiple-comparisons test, ${ }^{*} p \leq 0.05$.

and acquisition of amoeboid morphology revealed by immunostaining with anti-F4/80, indicating microglial polarization to an activated state (Fig. $3 A, B$ ). A $\beta \mathrm{O}$-induced morphological changes were prevented by prior treatment of cultures with $1 \mu \mathrm{M} 5-\mathrm{HT}$ (Fig. 3C-E). Similar results were obtained using integrated F4/80 immunofluorescence as an indicator of microglial activation (Fig. $3 F$ ).

We next measured TNF- $\alpha$ expression in microglial cultures and its release to the culture medium. Consistent with microglial activation, TNF- $\alpha$ mRNA levels were increased in cells exposed for $2 \mathrm{~h}$ to $\mathrm{A} \beta \mathrm{O}$ s (Fig. $3 G$ ) and this was followed by increased levels of TNF- $\alpha$ and nitric oxide in the medium after 24 h of exposure to A $\beta$ Os (Fig. $3 H, I$ ). This proinflammatory response was blocked fully by pretreatment of cultures with 5-HT (Fig. $3 H, I$ ).
We demonstrated recently that $\mathrm{A} \beta \mathrm{O}$ s induce activation of $\mathrm{I} \kappa \mathrm{B}$ kinase in hippocampal neurons (Bomfim et al., 2012), which leads to activation of $\mathrm{NF} \kappa \mathrm{B}$ signaling. Nuclear translocation of $\mathrm{NF} \kappa \mathrm{B}$ activates transcription of several inflammation-related genes, including TNF- $\alpha$. To further characterize the activation of microglia by $\mathrm{A} \beta \mathrm{O}$, we investigated whether $\mathrm{A} \beta \mathrm{O}$ s induced $\mathrm{NF} \kappa \mathrm{B}$ translocation to the nucleus. Exposure of microglial cultures to $\mathrm{A} \beta \mathrm{O}$ s induced a marked increase in $\mathrm{NF} \kappa \mathrm{B}$ p65-positive nuclei (Fig. 4). Pretreatment of cells with 5 -HT prevented the translocation of $\mathrm{NF} \kappa \mathrm{B}$ to the nucleus (Fig. $4 J-M)$. These findings demonstrate that $\mathrm{A} \beta \mathrm{O}$ s activate microglia directly, triggering nuclear translocation of $\mathrm{NF} \kappa \mathrm{B}$ and increased TNF- $\alpha$ production and release. Results further indicate a novel action of 5-HT in blocking microglial activation and counteracting the impact of $\mathrm{A} \beta \mathrm{O}$. 


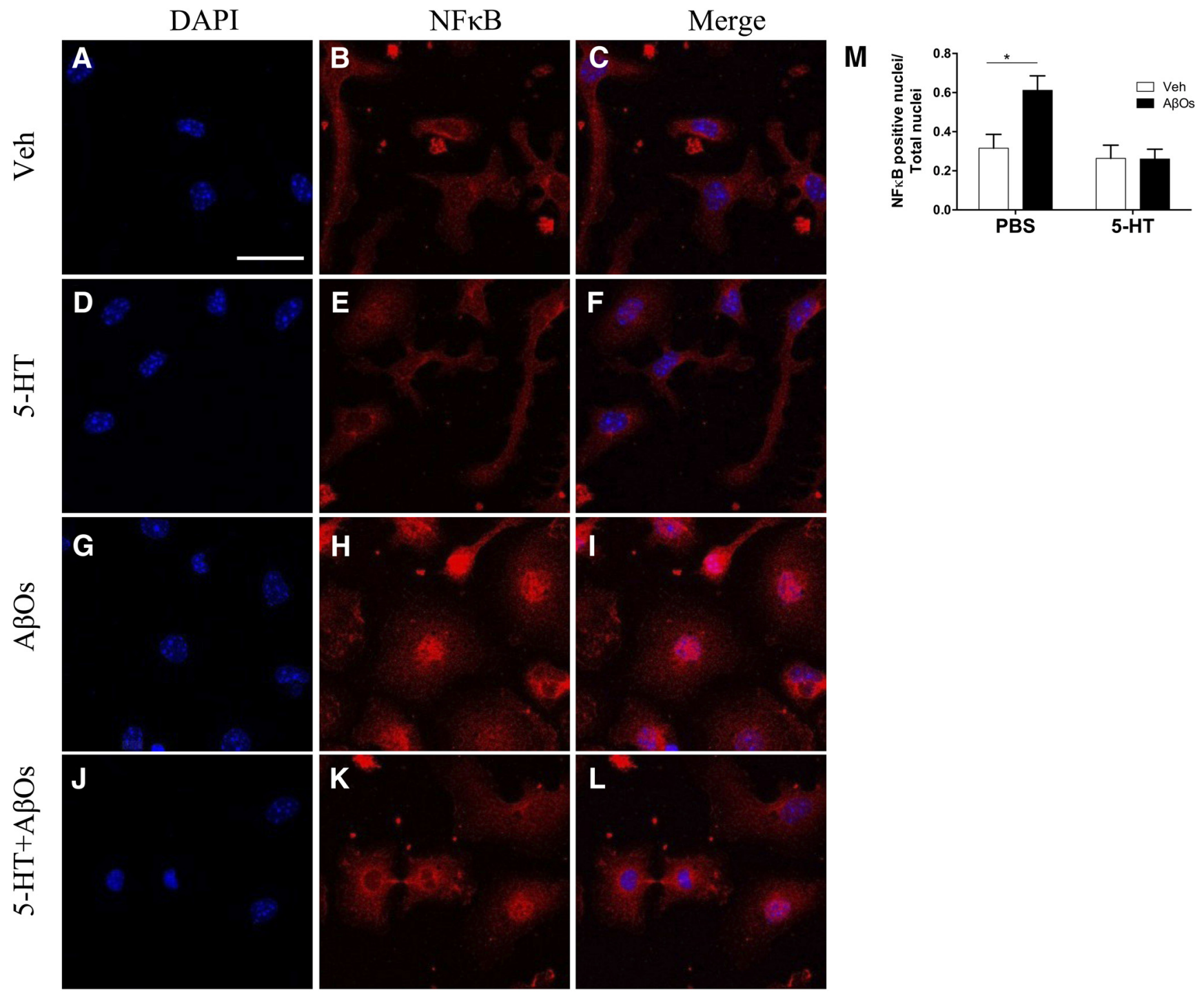

Figure 4. 5 -HT prevents $\mathrm{A} \beta 0$-induced nuclear translocation of NF $\kappa \mathrm{B}$ (p65 subunit) in microglia. $A-L$, Microglial cultures were pretreated with $1 \mu \mathrm{M} 5-\mathrm{HT}$ for 30 min (as indicated) before the addition of $100 \mathrm{~nm} \mathrm{~A} \beta 0$ s (or vehicle) and incubation for $2 \mathrm{~h}$. Cells were fixed, permeabilized, and incubated with anti-NF $\kappa B$ p65 (red) and DAPI (blue). Scale bar, $50 \mu \mathrm{m} . M, \mathrm{NF} \kappa \mathrm{B}$ p65-positive nuclei were counted and are shown relative to total nuclei. Error bars indicate means $\pm \mathrm{SEM} ; n=5$ independent microglial cultures, $2-3$ coverslips per experimental condition per culture, 10 images acquired per coverslip; two-way ANOVA followed by Dunnett's multiple-comparisons test, ${ }^{*} p \leq 0.05$.

\section{Abnormal activation of microglial TLR4 underlies A $\beta$ O-induced depressive-like behavior}

Glial cells expressing high levels of TLR4 have been found surrounding plaques in $\mathrm{AD}$ brains and TLR4 levels are significantly increased in the brains of transgenic mouse models of $\mathrm{AD}$ (Heneka et al., 2014; Trotta et al., 2014; Heneka et al., 2015). Moreover, TLR4 expression has been reported to increase neuronal vulnerability to damage induced by fibrillar preparations of $\mathrm{A} \beta$ (Walter et al., 2007). These findings prompted us to investigate the involvement of TLR4 in microglial activation and depressive-like behavior induced by A $\beta O s$. Significantly, A $\beta O s$ failed to induce increased immobility in the FST and anhedonic behavior (decreased preference for sucrose over water) in TLR $4^{-1-}$ mice (Fig. $5 A, B$ ). Lack of TLR4 further prevented the decrease in 5-HT levels in the hippocampus of mice infused with A $\beta$ Os (Fig. $5 C$ ).

Finally, to determine the specific role of TLR4 in myeloid cells in depressive-like behavior, we used chimeric mice in which cells of myeloid lineage were replaced by cells derived from $\mathrm{CH} 3 / \mathrm{HeJ}$ mice harboring a spontaneous loss-of-function mutation that renders TLR4 unresponsive to LPS (Poltorak et al., 1998). Remarkably, such animals were completely resistant to the increase in immobility time in the FST induced by intracerebroventricular infusion of $\mathrm{A} \beta \mathrm{Os}$ (Fig. $5 D$ ), establishing that abnormal TLR4 activation underlies $\mathrm{A} \beta \mathrm{O}$-induced depressive-like behavior in mice.

\section{Discussion}

Although clinical and epidemiological studies have revealed a strong connection between $\mathrm{AD}$ and depression, the mechanisms connecting these disorders at the molecular and cellular levels remain to be elucidated. Here, we show that $A \beta O s$, which were linked previously to neuronal dysfunction and memory impairment in $\mathrm{AD}$, induce depressive-like behavior in mice through TLR4-dependent microglial activation and aberrant TNF- $\alpha$ signaling. These results provide insight into the biological mechanisms underlying the clinical link between $\mathrm{AD}$ and depression. 


\section{A}
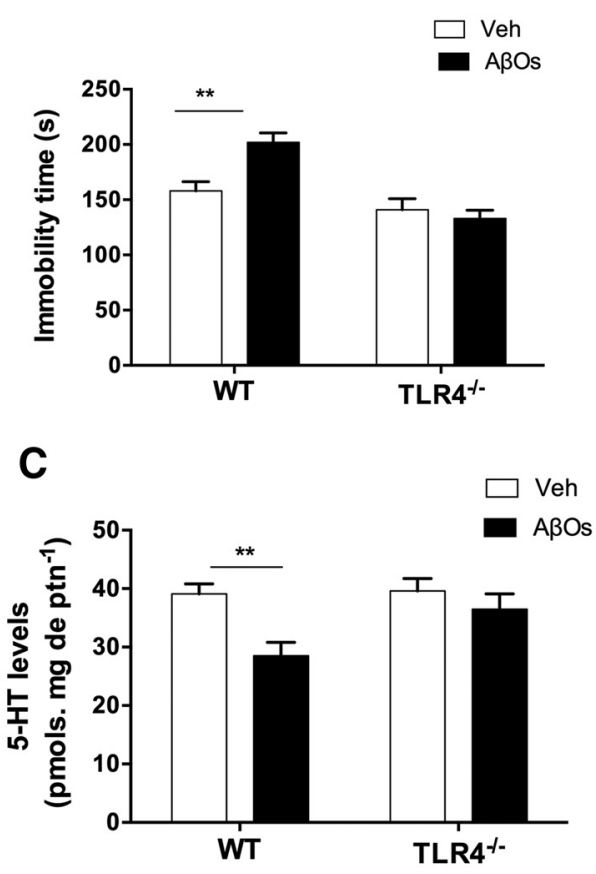

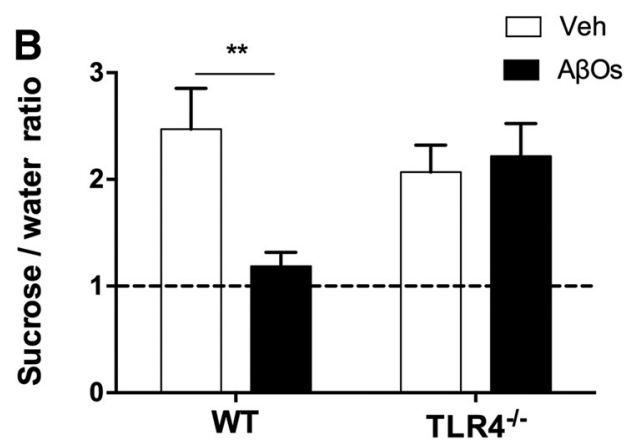

D

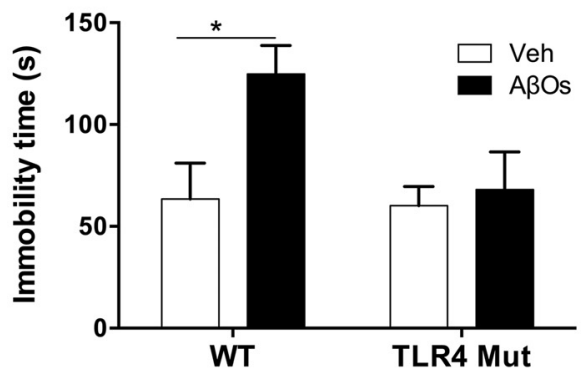

Figure 5. TLR4-dependent induction of depressive-like behavior by $A \beta 0$ s. TLR4 ${ }^{-1-}$ mice were infused intracerebroventricularly with $A \beta 0$ s $(10$ pmol) or vehicle. FST $(A)$ or sucrose preference test $(\boldsymbol{B})$ was performed $24 \mathrm{~h}$ after $\mathrm{A} \beta 0$ infusion. $\boldsymbol{C}, 5$-HT levels measured in the hippocampus of A $\beta 0$-infused mice. Error bars indicate means \pm SEM; $n=12-18 \mathrm{mice}$ per group in the FST; $n=5-7$ per group in the sucrose preference test and 5-HT determination; two-way ANOVA followed by Dunnett's multiple-comparisons test, ${ }^{*} p \leq 0.05$, ${ }^{* *} p \leq 0.01$. $D$, After whole-body irradiation, mice received BMT from C $3 \mathrm{H} / \mathrm{HeJ}$ (TLR4-mutant) or C $3 \mathrm{H} / \mathrm{HePas}$ (WT) mice (see "Materials and Methods"). Transplanted mice were infused intracerebroventricularly with $10 \mathrm{pmol}$ of A 30 s or vehicle. FST was performed $24 \mathrm{~h}$ after $A \beta 0$ injection. Error bars indicate means $\pm \mathrm{SEM} ; n=7-8$ mice per experimental group; two-way ANOVA followed by Dunnett's multiple-comparisons test, ${ }^{*} p \leq 0.05$.

A large body of evidence indicates that depression is associated with chronic, low-grade inflammation (Dantzer et al., 2008). Inflammation is a complex process and involves both soluble factors and specialized cells that are mobilized to neutralize threats and restore normal body physiology. In the brain, glial cells, especially astrocytes and microglia, undergo activation under proinflammatory conditions, increasing the production of proinflammatory cytokines. Chronic inflammation becomes deleterious and leads to progressive brain damage and neurodegeneration (Wyss-Coray and Mucke, 2002; Heneka et al., 2014, 2015), playing a critical role in the pathogenesis of AD. Consistent with our finding of increased TNF- $\alpha$ levels in the brains of mice infused intracerebroventricularly with $\mathrm{A} \beta \mathrm{O}$ s, several studies have demonstrated the presence of inflammatory markers in the $\mathrm{AD}$ brain, including elevated levels of cytokines/chemokines and gliosis (notably microgliosis) in damaged regions (Czirr and Wyss-Coray, 2012; Wyss-Coray and Rogers, 2012; Heneka et al., 2014, 2015). Moreover, a recent meta-analysis indicated that blood concentrations of several inflammatory mediators, including TNF- $\alpha$, IL-6, and IL- $1 \beta$, are increased in AD patients (Swardfager et al., 2010), which is consistent with our finding of elevated levels of circulating sTNFR1, a proxy of TNF- $\alpha$ signaling, in the plasma of $A D$ patients. Current results further revealed increased brain levels of sTNFR1 after intracerebroventricular infusion of $\mathrm{A} \beta \mathrm{O}$ s in mice. It is also noteworthy that patients with major depressive disorder exhibit elevated levels of circulating sTNFR1 (Grassi-Oliveira et al., 2009), supporting the notion that aberrant TNF- $\alpha$ signaling provides a mechanistic link between AD and depression.

We further considered the possibility that additional proteins implicated in depression in humans or in depressive-like behavior in animal models might be affected by $\mathrm{A} \beta \mathrm{Os}$ in the mouse brain. However, we could not detect any changes in expression of p11, BDNF, Ido-1, or Gata-1 in the brains of oligomer-injected mice, indicating that $\mathrm{A} \beta \mathrm{O}$ s deregulated TNF- $\alpha$ signaling selectively. In the brain, TNF- $\alpha$ is mainly secreted by microglia in response to trauma, infection, or abnormal accumulation of protein aggregates (Park and Bowers, 2010). Significantly, we demonstrated recently that $\mathrm{A} \beta \mathrm{O}$ s induce astrocytic and microglial activation in the brains of mice (Ledo et al., 2013) and macaques (Forny-Germano et al., 2014). Consistent with a central role of microglia in behavioral changes induced by $\mathrm{A} \beta \mathrm{O}$, microglia $\mathrm{ab}-$ lation or pharmacological inhibition of microglial polarization to a proinflammatory state blocked behavioral alterations induced by $\mathrm{A} \beta \mathrm{Os}$ in mice.

Previous studies have shown that proinflammatory cytokines alter the metabolism of 5-HT (Tuglu et al., 2003; Wichers et al., 2005; Tyring et al., 2006; Zhu et al., 2006; Dantzer et al., 2008), a neurotransmitter closely associated with depressive behavior (Nestler et al., 2002). Altered 5-HT levels and serotonergic signaling have also been implicated in $\mathrm{AD}$ (Zarros et al., 2005; Kepe et al., 2006; Lorke et al., 2006; Lezoualc'h, 2007; Cirrito et al., 2011; Geldenhuys and Van der Schyf, 2011). The current results established that $\mathrm{A} \beta \mathrm{O}$ s reduced 5-HT levels in the mouse brain and this effect was prevented by minocycline treatment, implicating microglia in deregulated serotonergic signaling. Moreover, reducing brain 5-HT levels using a selective inhibitor of tryptophan hydroxylase led to increased brain levels of TNF- $\alpha$ in mice. We further found that 5-HT blocked A $\beta \mathrm{O}-$ induced microglial activation in vitro and, notably, the increase in brain TNF- $\alpha$ levels in oligomer-injected mice. These findings point to a novel key role of 5-HT in the physiological regulation of microglial activation and in pathological $\mathrm{A} \beta \mathrm{O}$ induced brain inflammation in AD. 
Supporting this connection, recent studies have shown that $5 \mathrm{HT}(2 \mathrm{~A})$ receptor agonists exhibit anti-inflammatory actions (Yu et al., 2008; Nau et al., 2013). It appears, therefore, that a cross talk between serotonergic signaling and brain innate immunity plays a major role in regulating inflammation and its consequences in both physiological conditions and in the pathophysiology of $\mathrm{AD}$ or depression.

The mechanism by which $A \beta O$ s reduce 5 -HT levels remains unknown. It is possible, for example, that $\mathrm{A} \beta \mathrm{O}$-induced inflammation modulates the levels or activity of an enzyme involved in 5-HT metabolism. A plausible target is Ido-1, which diverts tryptophan to the kynurenine pathway, thus decreasing $5-\mathrm{HT}$ production. Ido-1 can be activated by a number of cytokines, including IFN- $\gamma$ and TNF- $\alpha$ (Dantzer et al., 2008). Ido- 1 is present in accessory immune cells, including macrophages and dendritic cells, as well as in microglia, and is ubiquitously expressed, including in the brain (Wirleitner et al., 2003). The enzymatic activity of Ido-1 is enhanced in conditions of acute or chronic activation of the immune system, such as immunotherapy, AIDS, atherosclerosis and coronary heart disease, rheumatoid arthritis, and obesity (Wirleitner et al., 2003). Although we did not detect changes in expression of Ido- 1 in the brains of $\mathrm{A} \beta \mathrm{O}$-infused mice, it is possible that $\mathrm{A} \beta \mathrm{O}$ s upregulate Ido- 1 activity without affecting its mRNA levels. Although the precise mechanism by which $\mathrm{A} \beta \mathrm{O}$ s decrease brain 5 -HT levels remains to be elucidated, recent data suggest that 5-HT deficiency increases stress vulnerability and impairs the antidepressant response after psychosocial stress (Sachs et al., 2015).

TLRs are transmembrane pattern recognition receptors that trigger signals in response to diverse pathogen-associated molecular patterns or damage-associated molecular patterns. It has been shown that TLRs, classically thought to respond to pathogens, can be activated in the absence of microbial infection (Wyss-Coray and Mucke, 2002) and regulate neurogenesis (Czirr and Wyss-Coray, 2012). Glial cells surrounding $A \beta$ plaques in AD brains express high levels of TLR4 (Walter et al., 2007; Okun et al., 2009). Moreover, APP-transgenic mice, which accumulate $\mathrm{A} \beta$ deposits progressively, exhibit significant increases in brain expression of TLR4 compared with their wild-type littermates (Walter et al., 2007) and TLR4 expression increases neuronal vulnerability to $A \beta$-induced damage (Tang et al., 2008). The current results show that the impact of $\mathrm{A} \beta \mathrm{O}$ s on mouse behavior is abrogated in TLR ${ }^{-1-}$ in mice and in chimeric mice harboring a nonfunctional missense mutated form of TLR4 selectively in cells of myeloid origin. Our results thus indicate that microglial TLR4 activation by $\mathrm{A} \beta \mathrm{O}$ s triggers depressive-like behavior in mice.

Because the results presented here and in other studies point to inflammation as a central event in both depression and $\mathrm{AD}$, it is tempting to speculate that anti-inflammatory drugs might be used to treat depression in AD. This proposal, however, should be regarded with caution. For example, Warner-Schmidt et al. (2011) have shown that ibuprofen and other nonsteroidal antiinflammatory drugs (NSAIDs) block the antidepressant effects of selective serotonin reuptake inhibitors (SSRIs). In particular, NSAIDs abrogate the therapeutic actions of SSRIs by inhibiting the formation of brain TNF- $\alpha$. Moreover, microglia are responsible for chemokine-mediated sensing and clearance of $A \beta$ in the brain, so generalized inhibition of microglial function might be detrimental in terms of compromising $\mathrm{A} \beta$ clearance, promoting its oligomerization, and leading to increased neurotoxicity. Future studies are warranted to address the complexity of the interplay among brain inflammation, serotonergic signaling, and depressive behavior with the goal of determining ways to rebal- ance microglial activity to promote its beneficial actions and limit microglia-mediated damage.

A full understanding of how depression develops in $\mathrm{AD}$ remains a challenging problem that has addressed by very few studies to date. Our findings raise the possibility that TLR4-dependent microglial activation, brain inflammation, and downregulation of 5-HT levels in response to $\mathrm{A} \beta \mathrm{O}$ s contribute to the development of depression in $\mathrm{AD}$. This may pave the way for the development of novel AD therapeutics aimed at boosting brain 5-HT levels and rebalancing microglial function.

\section{References}

Krishnan V, Nestler EJ (2008) The molecular neurobiology of depression. Nature 455:894-902. CrossRef Medline

Autry AE, Adachi M, Nosyreva E, Na ES, Los MF, Cheng PF, Kavalali ET, Monteggia LM (2011) NMDA receptor blockade at rest triggers rapid behavioural antidepressant responses. Nature 475:91-95. CrossRef Medline

Azevedo EP, Ledo JH, Barbosa G, Sobrinho M, Diniz L, Fonseca AC, Gomes F, Romão L, Lima FR, Palhano FL, Ferreira ST, Foguel D (2013) Activated microglia mediate synapse loss and short-term memory deficits in a mouse model of transthyretin-related oculoleptomeningeal amyloidosis. Cell Death Dis 4:e789. CrossRef Medline

Benilova I, De Strooper B (2013) Promiscuous Alzheimer's amyloid: yet another partner. Science 341:1354-1355. CrossRef Medline

Bie B, Wu J, Yang H, Xu JJ, Brown DL, Naguib M (2014) Epigenetic suppression of neuroligin 1 underlies amyloid-induced memory deficiency. Nat Neurosci 17:223-231. CrossRef Medline

Bomfim TR, Forny-Germano L, Sathler LB, Brito-Moreira J, Houzel JC, Decker H, Silverman MA, Kazi H, Melo HM, McClean PL, Holscher C, Arnold SE, Talbot K, Klein WL, Munoz DP, Ferreira ST, De Felice FG (2012) An anti-diabetes agent protects the mouse brain from defective insulin signaling caused by Alzheimer's disease: associated $A \beta$ oligomers. J Clin Invest 122:1339-1353. CrossRef Medline

Bonaccorso S, Lin A, Song C, Verkerk R, Kenis G, Bosmans E, Scharpe S, Vandewoude M, Dossche A, Maes M (1998) Serotonin-immune interactions in elderly volunteers and in patients with Alzheimer's disease (DAT): lower plasma tryptophan availability to the brain in the elderly and increased serum interleukin-6 in DAT. Aging (Milano) 10:316-323. Medline

Caramelli P, Barbosa MT, Sakurai E, Santos Dos EL, Beato RG, Machado JC, Guimarães HC, Teixeira AL, Pietà Study Group (2011) The Pietà study: epidemiological investigation on successful brain aging in Caeté (MG), Brazil. Methods and baseline cohort characteristics. Arq Neuropsiquiatr 69:579-584. CrossRef Medline

Cirrito JR, Disabato BM, Restivo JL, Verges DK, Goebel WD, Sathyan A, Hayreh D, D’Angelo G, Benzinger T, Yoon H, Kim J, Morris JC, Mintun MA, Sheline YI (2011) Serotonin signaling is associated with lower amyloid- $\beta$ levels and plaques in transgenic mice and humans. Proc Natl Acad Sci U S A 108:14968-14973. CrossRef Medline

Czirr E, Wyss-Coray T (2012) The immunology of neurodegeneration. J Clin Invest 122:1156-1163. CrossRef Medline

Dantzer R, O'Connor JC, Freund GG, Johnson RW, Kelley KW (2008) From inflammation to sickness and depression: when the immune system subjugates the brain. Nat Rev Neurosci 9:46-56. CrossRef Medline

Ferreira ST, Klein WL (2011) The A $\beta$ oligomer hypothesis for synapse failure and memory loss in Alzheimer's disease. Neurobiol Learn Mem 96: 529-543. CrossRef Medline

Figueiredo CP, Clarke JR, Ledo JH, Ribeiro FC, Costa CV, Melo HM, MotaSales AP, Saraiva LM, Klein WL, Sebollela A, De Felice FG, Ferreira ST (2013) Memantine rescues transient cognitive impairment caused by high-molecular-weight a $\beta$ oligomers but not the persistent impairment induced by low-molecular-weight oligomers. J Neurosci 33:9626-9634. CrossRef Medline

Filali M, Lalonde R, Rivest S (2009) Cognitive and non-cognitive behaviors in an APPswe/PS1 bigenic model of Alzheimer's disease. Genes Brain Behav 8:143-148. CrossRef Medline

Forny-Germano L, Lyra e Silva NM, Batista AF, Brito-Moreira J, Gralle M, Boehnke SE, Coe BC, Lablans A, Marques SA, Martinez AM, Klein WL, Houzel JC, Ferreira ST, Munoz DP, De Felice FG (2014) Alzheimer's 
disease-like pathology induced by amyloid- $\beta$ oligomers in nonhuman primates. J Neurosci 34:13629-13643. CrossRef Medline

Frye CA, Walf AA (2009) Progesterone reduces depression-like behavior in a murine model of Alzheimer's disease. Age 31:143-153. CrossRef Medline

Geerlings MI, den Heijer T, Koudstaal PJ, Hofman A, Breteler MM (2008) History of depression, depressive symptoms, and medial temporal lobe atrophy and the risk of Alzheimer disease. Neurology 70:1258-1264. CrossRef Medline

Geldenhuys WJ, Van der Schyf CJ (2011) Role of serotonin in Alzheimer's disease: a new therapeutic target? CNS Drugs 25:765-781. CrossRef Medline

Grassi-Oliveira R, Brietzke E, Pezzi JC, Lopes RP, Teixeira AL, Bauer ME (2009) Increased soluble tumor necrosis factor- $\alpha$ receptors in patients with major depressive disorder. Psychiatry and Clinical Neurosciences 63:202-208. CrossRef Medline

Green RC, Cupples LA, Kurz A, Auerbach S, Go R, Sadovnick D, Duara R, Kukull WA, Chui H, Edeki T, Griffith PA, Friedland RP, Bachman D, Farrer L (2003) Depression as a risk factor for Alzheimer disease: the MIRAGE Study. Arch Neurol 60:753-759. CrossRef Medline

Heneka MT, Kummer MP, Latz E (2014) Innate immune activation in neurodegenerative disease. Nat Rev Immunol 14:463-477. CrossRef Medline

Heneka MT, Golenbock DT, Latz E (2015) Innate immunity in Alzheimer's disease. Nat Immunol 16:229-236. CrossRef Medline

Kang HJ, Voleti B, Hajszan T, Rajkowska G, Stockmeier CA, Licznerski P, Lepack A, Majik MS, Jeong LS, Banasr M, Son H, Duman RS (2012) Decreased expression of synapse-related genes and loss of synapses in major depressive disorder. Nat Med 18:1413-1417. CrossRef Medline

Kepe V, Barrio JR, Huang SC, Ercoli L, Siddarth P, Shoghi-Jadid K, Cole GM, Satyamurthy N, Cummings JL, Small GW, Phelps ME (2006) Serotonin $1 \mathrm{~A}$ receptors in the living brain of Alzheimer's disease patients. Proc Natl Acad Sci U S A 103:702-707. CrossRef Medline

Kobayashi K, Imagama S, Ohgomori T, Hirano K, Uchimura K, Sakamoto K, Hirakawa A, Takeuchi H, Suzumura A, Ishiguro N, Kadomatsu K (2013) Minocycline selectively inhibits M1 polarization of microglia. Cell Death Dis 4:e525. CrossRef Medline

Lambert MP, Barlow AK, Chromy BA, Edwards C, Freed R, Liosatos M, Morgan TE, Rozovsky I, Trommer B, Viola KL, Wals P, Zhang C, Finch CE, Krafft GA, Klein WL (1998) Diffusible, nonfibrillar ligands derived from Abeta1-42 are potent central nervous system neurotoxins. Proc Natl Acad Sci U S A 95:6448-6453. CrossRef Medline

Lambert MP, Velasco PT, Chang L, Viola KL, Fernandez S, Lacor PN, Khuon D, Gong Y, Bigio EH, Shaw P, De Felice FG, Krafft GA, Klein WL (2007) Monoclonal antibodies that target pathological assemblies of Abeta. J Neurochem 100:23-35. CrossRef Medline

Ledo JH, Azevedo EP, Clarke JR, Ribeiro FC, Figueiredo CP, Foguel D, De Felice FG, Ferreira ST (2013) Amyloid- $\beta$ oligomers link depressive-like behavior and cognitive deficits in mice. Mol Psychiatry 18:1053-1054. CrossRef Medline

Lezoualc'h F (2007) 5-HT4 receptor and Alzheimer's disease: the amyloid connection. Exp Neurol 205:325-329. CrossRef Medline

Lorke DE, Lu G, Cho E, Yew DT (2006) Serotonin 5-HT2A and 5-HT6 receptors in the prefrontal cortex of Alzheimer and normal aging patients. BMC Neurosci 7:36. CrossRef Medline

Lourenco MV et al. (2013) TNF- $\alpha$ mediates PKR-dependent memory impairment and brain IRS-1 inhibition induced by Alzheimer's $\beta$-amyloid oligomers in mice and monkeys. Cell Metab 18:831-843. CrossRef Medline

Lyketsos CG, Olin J (2002) Depression in Alzheimer's disease: overview and treatment. Biol Psychiatry 52:243-252. CrossRef Medline

Mucke L, Selkoe DJ (2012) Neurotoxicity of amyloid $\beta$-protein: synaptic and network dysfunction. Cold Spring Harb Perspect Med 2:a006338. CrossRef Medline

Nau F Jr, Yu B, Martin D, Nichols CD (2013) Serotonin 5-HT2A receptor activation blocks TNF- $\alpha$ mediated inflammation in vivo. PLoS One 8:e75426. CrossRef Medline

Nestler EJ, Barrot M, DiLeone RJ, Eisch AJ, Gold SJ, Monteggia LM (2002) Neurobiology of depression. Neuron 34:13-25. CrossRef Medline

Okun E, Griffioen KJ, Lathia JD, Tang SC, Mattson MP, Arumugam TV (2009) Toll-like receptors in neurodegeneration. Brain Res Rev 59:278292. CrossRef Medline

Ownby RL, Crocco E, Acevedo A, John V, Loewenstein D (2006) Depres- sion and risk for Alzheimer disease: systematic review, meta-analysis, and metaregression analysis. Arch Gen Psychiatry 63:530-538. CrossRef Medline

Park KM, Bowers WJ (2010) Tumor necrosis factor-alpha mediated signaling in neuronal homeostasis and dysfunction. Cell Signal 22:977-983. CrossRef Medline

Poltorak A, He X, Smirnova I, Liu MY, Van Huffel C, Du X, Birdwell D, Alejos E, Silva M, Galanos C, Freudenberg M, Ricciardi-Castagnoli P, Layton B, Beutler B (1998) Defective LPS signaling in C3H/HeJ and C57BL/ 10ScCr mice: mutations in Tlr4 gene. Science 282:2085-2088. CrossRef Medline

Porsolt RD, Le Pichon M, Jalfre M (1977) Depression: a new animal model sensitive to antidepressant treatments. Nature 266:730-732. CrossRef Medline

Rodríguez JJ, Noristani HN, Verkhratsky A (2012) The serotonergic system in ageing and Alzheimer's disease. Prog Neurobiol 99:15-41. CrossRef Medline

Romano A, Pace L, Tempesta B, Lavecchia AM, Macheda T, Bedse G, Petrella A, Cifani C, Serviddio G, Vendemiale G, Gaetani S, Cassano T (2014) Depressive-like behavior is paired to monoaminergic alteration in a murine model of Alzheimer's disease. Int J Neuropsychopharmacol 18: pii: pyu020. CrossRef Medline

Sachs BD, Ni JR, Caron MG (2015) Brain 5-HT deficiency increases stress vulnerability and impairs antidepressant responses following psychosocial stress. Proc Natl Acad Sci U S A 112:2557-2562. CrossRef Medline

Santos LE, Beckman D, Ferreira ST (2016) Microglial dysfunction connects depression and Alzheimer's disease. Brain Behav Immun 55:151-165. CrossRef Medline

Schmidt HD, Duman RS (2007) The role of neurotrophic factors in adult hippocampal neurogenesis, antidepressant treatments and animal models of depressive-like behavior. Behav Pharmacol 18:391-418. CrossRef Medline

Schmittgen TD, Livak KJ (2008) Analyzing real-time PCR data by the comparative $\mathrm{C}(\mathrm{T})$ method. Nat Protoc 3:1101-1108. CrossRef Medline

Selkoe DJ (2011) Alzheimer's disease. Cold Spring Harb Perspect Biol 3:a004457. CrossRef Medline

Starkstein SE, Mizrahi R (2006) Depression in Alzheimer's disease. Expert Rev Neurother 6:887-895. CrossRef Medline

Svenningsson P, Chergui K, Rachleff I, Flajolet M, Zhang X, El Yacoubi M, Vaugeois JM, Nomikos GG, Greengard P (2006) Alterations in 5-HT1B receptor function by p11 in depression-like states. Science 311:77-80. CrossRef Medline

Svenningsson P, Kim Y, Warner-Schmidt J, Oh YS, Greengard P (2013) p11 and its role in depression and therapeutic responses to antidepressants. Nat Rev Neurosci 14:673-680. CrossRef Medline

Swardfager W, Lanctôt K, Rothenburg L, Wong A, Cappell J, Herrmann N (2010) A meta-analysis of cytokines in Alzheimer's disease. Biol Psychiatry 68:930-941. CrossRef Medline

Tang SC, Lathia JD, Selvaraj PK, Jo DG, Mughal MR, Cheng A, Siler DA, Markesbery WR, Arumugam TV, Mattson MP (2008) Toll-like receptor- 4 mediates neuronal apoptosis induced by amyloid beta-peptide and the membrane lipid peroxidation product 4-hydroxynonenal. Exp Neurol 213:114-121. CrossRef Medline

Trotta T, Porro C, Calvello R, Panaro MA (2014) Biological role of Toll-like receptor-4 in the brain. J Neuroimmunol 268:1-12. CrossRef Medline

Tuglu C, Kara SH, Caliyurt O, Vardar E, Abay E (2003) Increased serum tumor necrosis factor-alpha levels and treatment response in major depressive disorder. Psychopharmacology (Berl) 170:429-433. CrossRef Medline

Tyring S, Gottlieb A, Papp K, Gordon K, Leonardi C, Wang A, Lalla D, Woolley M, Jahreis A, Zitnik R, Cella D, Krishnan R (2006) Etanercept and clinical outcomes, fatigue, and depression in psoriasis: double-blind placebo-controlled randomised phase III trial. Lancet 367:29-35. CrossRef Medline

van Rooijen N, Hendrikx E (2010) Liposomes for specific depletion of macrophages from organs and tissues. Methods Mol Biol 605:189-203. CrossRef Medline

Walter S, Letiembre M, Liu Y, Heine H, Penke B, Hao W, Bode B, Manietta N, Walter J, Schulz-Schuffer W, Fassbender K (2007) Role of the toll-like receptor 4 in neuroinflammation in Alzheimer's disease. Cell Physiol Biochem 20:947-956. CrossRef Medline

Warner-Schmidt JL, Vanover KE, Chen EY, Marshall JJ, Greengard P (2011) 
Antidepressant effects of selective serotonin reuptake inhibitors (SSRIs) are attenuated by antiinflammatory drugs in mice and humans. Proc Natl Acad Sci U S A 108:9262-9267. CrossRef Medline

Wichers MC, Koek GH, Robaeys G, Verkerk R, Scharpé S, Maes M (2005) IDO and interferon-alpha-induced depressive symptoms: a shift in hypothesis from tryptophan depletion to neurotoxicity. Mol Psychiatry 10: 538-544. CrossRef Medline

Wirleitner B, Neurauter G, Schröcksnadel K, Frick B, Fuchs D (2003) Interferon-gamma-induced conversion of tryptophan: immunologic and neuropsychiatric aspects. Curr Med Chem 10:1581-1591. CrossRef Medline Wyss-Coray T, Mucke L (2002) Inflammation in neurodegenerative disease-a double-edged sword. Neuron 35:419-432. CrossRef Medline

Wyss-Coray T, Rogers J (2012) Inflammation in Alzheimer disease-a brief review of the basic science and clinical literature. Cold Spring Harb Perspect Med 2:a006346. CrossRef Medline

Yu B, Becnel J, Zerfaoui M, Rohatgi R, Boulares AH, Nichols CD (2008) Serotonin 5-hydroxytryptamine(2A) receptor activation suppresses tumor necrosis factor-alpha-induced inflammation with extraordinary potency. J Pharmacol Exp Ther 327:316-323. CrossRef Medline

Zarros AC, Kalopita KS, Tsakiris ST (2005) Serotoninergic impairment and aggressive behavior in Alzheimer's disease. Acta Neurobiol Exp (Wars) 65:277-286. Medline

Zhu CB, Blakely RD, Hewlett WA (2006) The proinflammatory cytokines interleukin-1beta and tumor necrosis factor-alpha activate serotonin transporters. Neuropsychopharmacology 31:2121-2131. Medline 